\title{
The Comparison of Olsen, DMT-HFO and DGT Methods for Assessment of Plant Available Phosphorus in Soils
}

\author{
Saber Heidari ${ }^{\# 1}$, Adel Reyhanitabar ${ }^{\# 2}$, Shahin Oustan ${ }^{\# 3}$ \\ \# Soil Science Department, University of Tabriz, Tabriz, Iran \\ E-mail: ${ }^{1}$ s.heidari@tabrizu.ac.ir; ${ }^{2}$ areyhani@tabrizu.ac.ir; ${ }^{3}$ oustan@hotmail.com
}

\begin{abstract}
Phosphorus (P) is one of the most important limiting nutrients for crop production in the world soils. Excessive and deficiencies of $P$ in calcareous soils has been reported. Several methods can be used to recognize soil bioavailable phosphorus. Soil $P$ tests involve chemical extraction and ion-sink extractants. The diffusive gradient in thin-films (DGT) is a new technique for measuring available soil phosphorus. This technique attempts to simulate physico-chemical processes influencing the uptake of solutes by plant roots. Also, the dialysis membrane tubes filled with hydrous ferric oxide solution (DMT-HFO) has recently been used to assess P desorption over long-term laboratory studies. The DMT-HFO method acts like the DGT method. Both systems are based on Fick's law and try to imitate physicochemical uptake of $P$ by plant roots in soils. The aim of this research was to use Fick's law in the interpretation of DMT measurements and compare it with the Olsen and DGT methods for assessment of corn available phosphorus in some calcareous soils. For this purpose, the diffusion coefficients of $P$ in the DMT membrane and DGT gel were calculated. The DMT-HFOs were located in soil suspensions at $24,72,240$, and 500 hours and the concentration of DMT-HFO $\left(C_{D M T-H F O}\right)$ for $P$ in the mentioned times were compared with those of Olsen and DGT methods on assessing of corn $P$ uptake. Corn (SC 704) were grown in a greenhouse on ten different calcareous soils. Based on the results, the diffusion coefficient of $\mathrm{P}\left(\mathrm{H}_{2} \mathrm{PO}_{4}^{-}\right)$in $\left.\mathrm{DMT}_{(5.54} * 10^{-8} \mathrm{~cm}^{2} . \mathrm{s}^{-1}\right)$ was lower than that of DGT gel $\left(5.8 * 10^{-6} \mathrm{~cm}^{2} . \mathrm{s}^{-1}\right)$. The linear correlation coefficient(r) between $C_{D M T-H F O}$ and corn $P$ content was increased by the time (24- 500 hours). Based on the $r^{2}$ values, the lowest and highest correlations were related to $C_{D M T-H F O}$ in 24 hours $\left(r^{2}=0.22, p<0.05\right)$ and 500 hours $\left(r^{2}=0.9, p<0.05\right)$, respectively. The DMT-HFO provides a more precise correlation with $P$ uptake by corn $\left(r^{2}=0.9\right.$ in 500 hours) than Olsen $P\left(r^{2}=0.86\right)$ and $C_{E}$ (DGT) $\left(r^{2}=0.76\right)$. In roots, the best correlation between $C_{D M T-H F O}$ and corn $P$ uptake was obtained in 250 hours. However, in 24 to 250 hours, the statistical correlations based on $r^{2}$ values were very similar.
\end{abstract}

Keywords - DGT; DMT-HFO; Olsen-P; Corn; Phosphorus

\section{INTRODUCTION}

This Phosphorus is an essential nutrient for all life forms and is involved in vital plant processes. Also phosphorus is one of the most important limiting plant nutrient [1]. So it's needed to add for crop growth. The diagnosis of phosphorus deficiency in agricultural ecosystems is important in order to avoid environmental pollution duo to over-applied in the form of fertilizers and to reduce effects on crop yields [2]. Many methods have been used to determinate nutrient deficiencies on plants including plant tissue analysis and soil tests. Plant tissue analysis is expensive and usually done when the crop have been become deficient but soil test is used prior to plant cultivation so fertilizers could be added [3]. Several methods can be used to recognize bioavailable phosphorus on soils. Soil P tests involve chemical extraction and ion-sink extractants. The most of these methods are based on chemical extractants, for example $\mathrm{NaHCO}_{3}$ solution [4], solution of acetate, ammonium nitrate, ammonium fluoride, nitric acid and EDTA (Mehlich extraction) [5] and $\mathrm{HCl}$ and ammonium fluoride solution [6]. But there is no agreement on which extractants are more acceptable for any type of soils [7]. Different extractants used for different soil types with different soil $\mathrm{pH}$, for instance Bray and Mehlich are acidic extractants and Olsen have been developed for alkaline soils [8].

The ion-sink extractants includes ionic exchange resin membranes, resin bags and iron oxides coated filter papers (Pi-test) [9]. The dialysis membrane tubes filled with hydrous ferric oxide (DMT-HFO) was a method that has been done on the long-term desorption kinetics study of soil $\mathrm{P}$ [10]. DMT-HFO acts as an infinite sink for $\mathrm{P}$ desorbed from soil. In contrast to $\mathrm{FeO}$-impregnated filter paper (Pitest) the DMT-HFO can be separated from soil suspension without contamination of the sink. Adhering soil particles may cause $\mathrm{FeO}$ paper to overestimate $\mathrm{P}$ desorption. Relatively, little information is available in the literature in relation to the use of this method [11]. 
Diffusive gradients in thin films (DGT) is a new technique for measuring soil available $\mathrm{P}$. This technique has been developed to assess element availability in natural water [12]. It has been proven this technique is suitable for evaluation of the metal bioavailability to plant, later on, DGT has been used for several years to assess bioavailable elements in waters and soils [13-15]. This technique is made up of a device that engage two layers of hydrogel, a diffusive layer and a binding layer. The DGT system basically is designed according to Fick's first law that ions diffuses through the diffusive gel layer and accumulate on binding gel layer [12]. The binding layer is made from polyacrylamide hydrogel impregnated with $\mathrm{Fe}$ oxide that acts as zero sink for phosphate. DGT employment on soils leads to decrease $\mathrm{P}$ in the soil solution and resupply from solid phase. Mason et al. [2] was compared dry matter or grain yield response to $\mathrm{P}$ fertilizer under field conditions versus available $\mathrm{P}$ that measured by three soil testing methods (DGT, anion exchange resin membrane, and Colwell P method) for wheat. Their results showed that DGT could successfully predict $\mathrm{P}$ content and can be used to improve prediction of fertilizer requirements and different factors like climate, wheat variety and soil type didn't have affected on DGT measurement while conventional method was a poor predictor of dry matter responses over a wide range of soil types. Six et al, [16] was declared that in tropical $\mathrm{P}$ deficient soils, DGT and $\mathrm{CaCl}_{2}$ measurement $\mathrm{P}$ have shown a better correlation with maize $\mathrm{P}$ content than Olsen, Colwell, Bray, Mehlich, and Ammonium oxalate methods. In this studies, DGT was a better indication for P requirements in plant than the extraction techniques. DMTHFO method acts like DGT. The both system are based on Fick's law and it seems that they try to imitate physicochemical uptake of $\mathrm{P}$ by plant roots in soil. Also, it seems that the theoretical interpretation of DGT measurements could be used on DMT-HFO measurements. So, the aim of this study was to use Fick's law in the interpretation of DMT measurements and to compare that with $\mathrm{P}$ content by corn plant, Olsen-P and DGT measurements in 10 calcareous soils.

\section{A. Olsen method Theory}

The Olsen method test is the most used method in world's calcareous soils and also in Iran. Olsen's method [4] is mainly based on phosphate solubility in calcareous soils though this method has been used in acid and neutral soils. In this method, it is believed that phosphate is replaced by bicarbonate, carbonate and hydroxide ions [17]. High $\mathrm{pH}$ of $\mathrm{NaHCO} 3$ solution decreases the activity of soil solution $\mathrm{Ca}^{2+}$ by precipitating as calcium carbonate, resulting in dissolution of $\mathrm{Ca}-\mathrm{P}$ and also $\mathrm{Fe}$ and Al-P compounds in calcareous and acid soils, respectively [18]. As an extractant, $\mathrm{NaHCO} 3$ acts through $\mathrm{pH}$ and ion effect to remove soil solution inorganic $\mathrm{P}$, plus some organic $\mathrm{P}$ and some labile solid-phase $\mathrm{P}$ compounds such as phosphate adsorbed to free lime, slightly soluble calcium phosphate precipitates, and phosphate loosely adsorbed to $\mathrm{Fe}$ and $\mathrm{Al}$ oxides and clay minerals.NaHCO3 also removes labile organic $\mathrm{P}$ forms that may be readily hydrolyzed to inorganic forms and contribute to plant-available $\mathrm{P}$ or be re-assimilated by microorganisms [18].

\section{B. DGT and DMT-HFO method Theory}

As shown in Fig. 1, a DGT device contains a binding layer (ferrihydrite impregnated gel for $\mathrm{P}$ ) overlain by diffusive gel and filter membrane (as a diffusive layer) that contacts the solution [19].

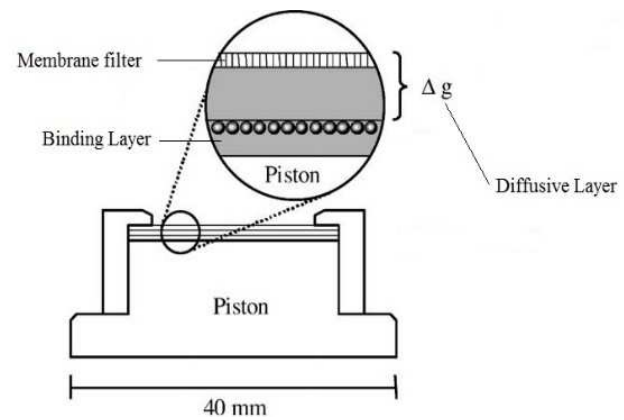

Fig. 1 Cross-section of a DGT device with binding and diffusive layer [19]

Also, DMT-HFO device consists on DMT strips as diffusive layer and hydrous ferric oxide solution as binding layer (Fig. 2).
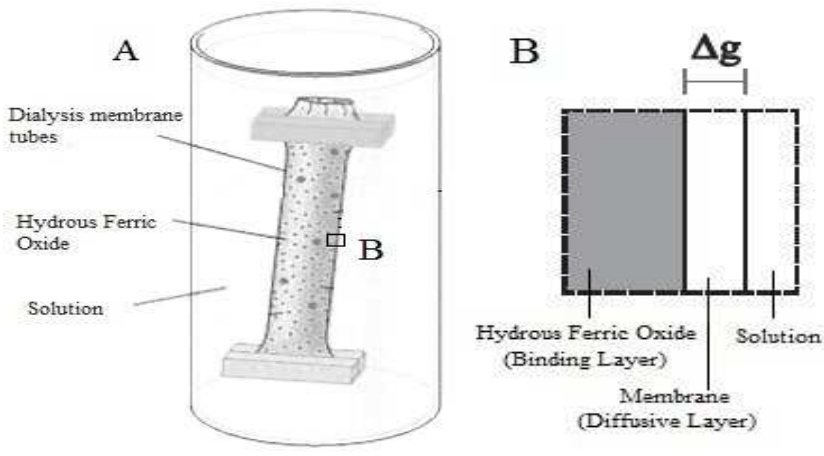

Fig. 2 Illustration of DMT-HFO device A: 3D and B: close up of the binding and diffusive layer on DMT-HFO

When DGT or DMT-HFO is deployed in solution, $\mathrm{P}$ diffused through the diffusive layer and immobilized at the binding layer. A concentration gradient is established within the diffusive layer (Fig. 3). Therefore, the flux of $\mathrm{P}$ through the diffusive layer is controlled by Fick's first law of diffusion (Eq. 1).

$$
\mathrm{F}=\mathrm{D} \mathrm{dC} / \mathrm{dX}
$$

Where, $\mathrm{F}$ is the flux of $\mathrm{P}$ per unit time and area, $\mathrm{D}$ is the diffusion coefficient in diffusive layer and $\mathrm{dC} / \mathrm{dx}$ is the concentration gradient in diffusive layer. The Eq. 1 could be written as follow in finite differences:

$$
\mathrm{F}=\mathrm{D}\left(\mathrm{C}-\mathrm{C}_{0}\right) / \Delta \mathrm{g}
$$

Where, $\mathrm{C}$ is the concentration of $\mathrm{P}$ at the solution and diffusive layer interface $\left(\mathrm{C}_{\mathrm{DGT}}\right.$ or $\left.\mathrm{C}_{\mathrm{DMT}-\mathrm{HFO}}\right), \mathrm{C}_{0}$ is the concentration of $\mathrm{P}$ at the binding layer interface and $\Delta \mathrm{g}$ is the thickness of the diffusive layer. According to the immobilizing of $\mathrm{P}$ on binding layer, $\mathrm{C}_{0}$ is zero. Also, the flux of $\mathrm{P}$ can be explained as $\mathrm{F}=\mathrm{M} / \mathrm{At}$. So, Eq. 2 becomes:

$$
\mathrm{C}=\mathrm{M} \Delta \mathrm{g} /(\mathrm{DAt})
$$


Where, $\mathrm{M}$ is the mass of $\mathrm{P}$ accumulated by the binding layer, $\mathrm{A}$ is the area of exposure diffusive layer $\left(3.14 \mathrm{~cm}^{2}\right.$ for DGT and $41.1 \mathrm{~cm}^{2}$ for DMT-HFO) and $\mathrm{t}(\mathrm{s})$ is deployment time.

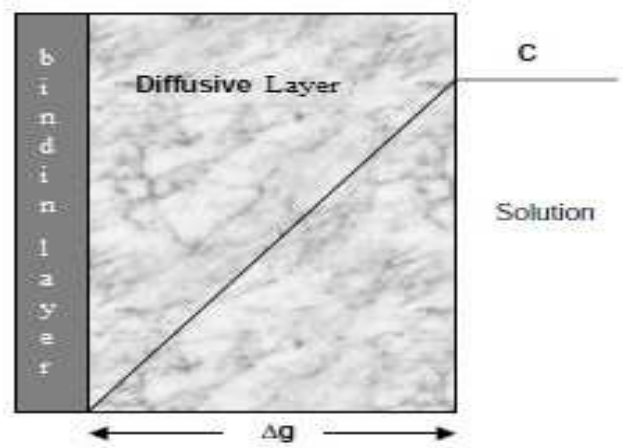

Fig. 3 Schematic representation of a DGT or DMT-HFO unit showing the concentration gradient through the diffusive layer [20].

\section{Calculation of effective concentration, $C_{E}$}

The concept of effective concentration $\left(\mathrm{C}_{\mathrm{E}}\right)$ is related to $\mathrm{P}$ concentration in the soil solution as well as the P resupplied from the solid phase as fully explained by Zhang et al. [13].The CE values can be calculated with CDGT by use of Eq. 4

$$
\mathrm{C}_{\mathrm{E}}=\mathrm{C}_{\mathrm{DGT}} / \mathrm{R}_{\text {diff }}
$$

$\mathrm{R}_{\text {diff }}$ is the extent of soil solution depletion at the DGT interface. For calculating $\mathrm{R}_{\text {diff, }}$, a $2 \mathrm{D}$ numerical model of the DGT-soil system was used; this is called 2D-DIFS (DGT Induced Fluxes in Sediments and Soils). The input parameters of DIFS in the calculation of $\mathrm{R}_{\text {diff }}$ were based on the "diffusion only" case that was described by Sochaczewski et al. [21]. Therefore, the calculation of CE from CDGT based on the input parameters $\left(\mathrm{Tc}=10^{10} \mathrm{~s}, \mathrm{Kd}=\right.$ $\left.10^{-10} \mathrm{~cm} 3 . \mathrm{g}^{-1}\right)$ and the diffusion case only depends on the $\%$ WHC (Water holding capacity) of soils.

\section{EXPERIMENTAL}

\section{A. Soil properties}

Ten different soil samples $(0-30 \mathrm{~cm})$ were collected from different fields in Azerbaijan, a province of Iran. Soils were primarily chosen based on the difference in soil textural class and available phosphorus content. All soils were air dried at room temperature. Soils used for analysis were sieved to $<2 \mathrm{~mm}$ and for pot trial were sieved to $<8 \mathrm{~mm}$. Some soil chemical and physical characteristics including $\mathrm{pH}$ in water at a soil/solution ratio of 1:2(w/v) [22], soil texture [23], calcium carbonate equivalent [24] and organic carbon by dichromate oxidation [25] were determined and presented in table 1 . Soil $\mathrm{P}$ analyses were performed by 0.5 M NaHCO3 (pH 8.5) solution as the extractant solution [4].

\section{B. Preparation of Dialysis Membrane Tubes filled with hydrous ferric oxide solution}

Fifty grams of ferric nitrate nonahydrate $\left(\mathrm{Fe}\left(\mathrm{NO}_{3}\right)_{3} \cdot 9 \mathrm{H}_{2} \mathrm{O}\right)$ were added to a $500 \mathrm{~mL}$ of deionized water. The $\mathrm{pH}$ of suspension was adjusted to $7-8$ using $1 \mathrm{M} \mathrm{NaOH}$ solution. Then, the suspension was centrifuged, elutriated, and resuspended in deionized water at least two times. Finally, the HFO suspension was brought to a volume of 1 liter and its $\mathrm{pH}$ was adjusted to 7 that is close to the $\mathrm{pH}$ of our soil suspension. Eleven centimeter length DMT strips (Scientific Laboratory Co., London. dialysis tubing: Visking, approximate pore size 1.5-2.0 nm, membrane thickness $0.075 \mathrm{~mm}$ ) were boiled for 5 minutes in deionized water and filled with $20 \mathrm{~mL}$ HFO suspension [26].

1) Diffusion coefficient of $P$ in DMT membrane: Diffusion coefficient of $\mathrm{P}$ in the DMT membrane was calculated using a diffusion cell in the pseudo steady state mode which has been described by Zhang and Davison [27] (Fig. 4). This cell was comprised two separate parts (A and B) that were linked together with a $3 \mathrm{~cm}$ diameter window that filled with a DMT membrane. One part was filled with deionized water (B) and another part with $100 \mathrm{mg} . \mathrm{kg}-1 \mathrm{P}$ solution (KH2PO4) (A). Finally, by measuring changes in the concentration of the $\mathrm{KH} 2 \mathrm{PO} 4$ solution, we were able to calculate the diffusion coefficient of KH2PO4 according to Zhang et al. procedure [28]. Using Eq. 6, the diffusion coefficient of $\mathrm{P}$ (H2PO4-) (D) was obtained from the salt diffusion coefficient (KH2PO4) (Ds).

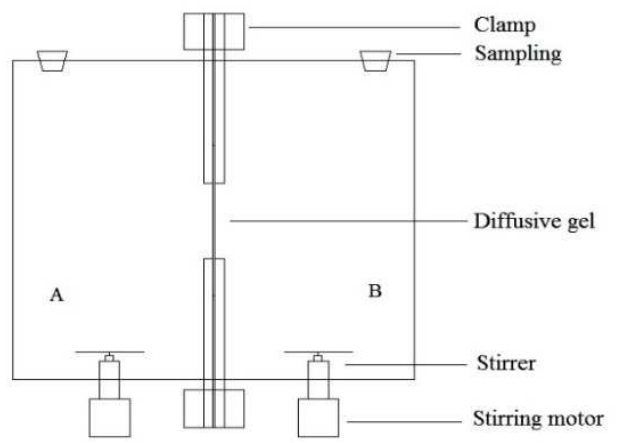

Fig. 4 Schematic representation of a diaphragm diffusion cell

$$
\text { Ds }=2 D . D_{k}\left(D+D_{k}\right)
$$

where $\mathrm{Dk}$ is the diffusion coefficient of the potassium and assumed to be same as for water [28].

\section{DGT method}

The DGT devices are consist of a two plastic plate (a backing plate and a front plate with a $2 \mathrm{~cm}$ diameter window) that holds two gels. The binding layer is placed at the back of diffusive layer so that the diffusive layer (ion-permeable gel) is exposed to the soil. A binding gel layer of $0.6 \mathrm{~mm}$ thickness and a $0.7 \mathrm{~mm}$ thick diffusive gel layer were used on the experiments. To prevent diffusive gel from being in touch with soil particles, a $100-\mu \mathrm{m}$-thick, $0.45-\mu \mathrm{m}$ pore size cellulose nitrate membrane was placed on top of the two gel layers [29].

1) Gel preparation: Acrylamide, agarose, ammonium persulfate, TEMED, Allylglycidyl ether, sodium borohydride, methanol and $\mathrm{NaOH}$ were purchased from Merck Millipore.

As a cross-linker, we were used allylagarose that was synthesized according to published procedure [30]. $33 \mathrm{mg}$ sodium borohydride and $1.6 \mathrm{~mL}$ allylglycidyl ether were 
added to a suspension of $1 \mathrm{~g}$ agarose in $\mathrm{NaOH}$ solution (33 $\mathrm{mL}, 0.3 \mathrm{M}$ ), under 12 hours stirring. After stirring periods, the derivative agarose was recovered by filtration and washed with distilled water to neutral $\mathrm{pH}$ and dehydrated with methanol and dried in an oven at $35^{\circ} \mathrm{C}$ [30].

Diffusive gel solution was prepared with $15 \%$ w/v acrylamide and $0.3 \% \mathrm{w} / \mathrm{v}$ allyl agarose (dissolving allyl agarose at distilled water at $95^{\circ} \mathrm{C}$ and cooling to $40^{\circ} \mathrm{C}$ ) [30]. $70 \mu \mathrm{l}$ ammonium persulphate $(10 \% \mathrm{w} / \mathrm{v})$ and $20 \mu \mathrm{l}$ of TEMED catalyst were added to $10 \mathrm{~mL}$ of the gel solution. The solution was cast between two glass plates separated by a plastic spacer of known thickness and allowed to polymerize at $42-46{ }^{\circ} \mathrm{C}$ for 1 hours. The gel was hydrated in deionized water for 24 hours. During this hydration, the gel was expanded to about $95 \%$ by weight and stored in $0.01 \mathrm{M}$ $\mathrm{NaNO}_{3}$ solution [27]. The binding layer is consisted ferrihydrite impregnated gel and were prepared according to the procedure described by Santner et al. [31]. After deployment, the DGTs were removed and rinsed with deionized water and disassembled. The binding gels taken out and after rinsing several times with deionized water were placed in $10 \mathrm{ml}$ of $0.25 \mathrm{M} \mathrm{H}_{2} \mathrm{SO}_{4}$ solution as an eluent and shacked for 2 hours. The gels were removed and $\mathrm{P}$ concentration in the eluent was measured colorimetrically by the malachite green method [32]. The mass of P (M) (Eq. 3) in the binding layer was calculated with following equation:

$$
\mathrm{M}=\mathrm{Ce}(\mathrm{V} \text { gel }+\mathrm{V} \text { acid })
$$

where $\mathrm{M}$ is calculated from $\mathrm{P}$ concentration in the eluent $\left(\mathrm{C}_{\mathrm{e}}\right)$, the volume of the elution $\left(\mathrm{V}_{\text {acid }}\right)$ and the volume of the binding gel $\left(\mathrm{V}_{\text {gel }}\right)$.

\section{Field study}

1) The DMT-HFO deployment to the soil: The DMTHFO were located in a plastic bottle containing $5 \mathrm{~g}$ of soil and $80 \mathrm{ml}$ of $0.03 \mathrm{M} \mathrm{KNO}_{3}$. One drops of thymol was added to inhibit microbial activity. After that, the bottles were shaken at 24, 72, 240, and 500 hours on an end-over-end shaker. At each time, DMT-HFO were brought out the plastic bottle and were cut open and the contents was dissolved by adding $0.5 \mathrm{~mL}$ of concentrated $\mathrm{H}_{2} \mathrm{SO}_{4}$. Then, the volume of dissolved HFO was adjusted to $100 \mathrm{~mL}$ with deionized water and analyzed for $\mathrm{P}$ colorimetrically using molybdate blue method [26].

2) The DGT deployment to the soil: Before deploying the DGT device to the soils, $50 \mathrm{~g}$ of the soils (oven dry weight based) were placed in a container. Soils were wetted with deionized water to saturation level by visual inspection the day prior to DGT deployment. At the next day, the DGT devices were placed at $22-24^{\circ} \mathrm{C}$ to ensure good contact between soil and exposure window of DGT. After 24 hours, the DGT device was removed and rinsed with deionized water and disassembled. The binding gel was removed and eluted in $10 \mathrm{~mL}$ of $0.25 \mathrm{M} \mathrm{H} 2 \mathrm{SO} 4$ solution. Blank DGTs were assembled for each deployment without any contact with the soils and analyzed in the same way as other DGTs [7].

3) Pot experiment: Three kilograms of air-dry soil was sieved to $<4.75 \mathrm{~mm}$ and filled into plastic pots. Soil moisture was maintained at approximately $80 \%$ FC before planting. Then six seeds of corn plant (Zea mays L.) single cross 704 variety were cultivated in the pots. After one week, seeds were thinned to three plants per pot. Soil water content maintained close-to-filled capacity, weighed every second day during plant growth. All required nutrients except $\mathrm{P}$ were used according to soil testing and customary fertilizer recommendations. For this, $120 \mathrm{mg}$ urea.kg-1, $10 \mathrm{mg}$ Zn.kg1 as zinc sulfate $(\mathrm{ZnSO} 4.7 \mathrm{H} 2 \mathrm{O})$ and $5 \mathrm{mg} \mathrm{Fe} . \mathrm{kg}-1$ of soil as FeEDDHA were applied. Since soils have enough available potassium, the potassium fertilizer was not used. Plants were grown in a condition of 14 hours' day, 10 hours' night and in a temperature of $28^{\circ} \mathrm{C}$.

After 60 days, the corn plant shoot and roots were harvested from soils, rinsed with deionized water, dried at $80^{\circ} \mathrm{C}$ to constant weight and finally powdered. Digestion of plant samples was done by wet oxidation method [33]. The concentration and content of $\mathrm{P}$ in plant samples were determined by the vanadomolybdate-yellow method [34]. Plant $\mathrm{P}$ content was calculating by $\mathrm{P}$ concentration in plant*plant dry matter. The three replicates were used for all experiments.

\section{RESULT AND DISCUSSION}

\section{A. Diffusion in gels and DMT}

The mass of phosphorus with time during a diffusion experiment in acrylamide gel and DMT at $25{ }^{\circ} \mathrm{C}$ are provided in figure 5. The diffusion coefficient of $\mathrm{P}_{\left(\mathrm{H}_{2} \mathrm{PO}_{4}{ }^{-}\right)}$ at $25{ }^{\circ} \mathrm{C}$ using an acrylamide gel $(15 \%$ by volume acrylamide and $0.3 \%$ by volume allylagarose cross-linker) was $5.8 * 10^{-6} \mathrm{~cm}^{2} \cdot \mathrm{s}^{-1}$. According to fig. 5, the diffusion coefficient of $\mathrm{KH}_{2} \mathrm{PO}_{4}$ in DMT was $1.1 * 10^{-7} \mathrm{~cm}^{2} . \mathrm{s}^{-1}$ that

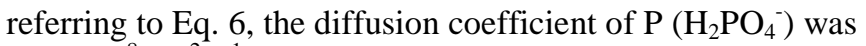
$5.54 * 10^{-8} \mathrm{~cm}^{2} . \mathrm{s}^{-1}$. Polyacrylamide gels are nonrestrictive and commonly used to separate proteins between 2000 to 200000Da. In which case the corresponding pore size will be about 2-9 nm diameter [35]. Also, Polyacrylamide gels when immersed in water swelling to $95 \%$ total volume of gel depending on the amount and type of cross-linker. This condition lets hydrated cations with radius of $0.2-0.3 \mathrm{~nm}$ to move freely through the gel [12]. Therefore, the diffusion coefficient of $\mathrm{P}$ in acrylamide gel was very closely to the diffusion coefficient of $\mathrm{P}$ in water (about 68\%). In DMT, diffusional properties were not known. The molecular weight cut-off of DMT is 12,000 to 14,000 Dalton that approximate pore size will be about 1.5-2.0 nm. Also, its structure doesn't have water like acrylamide gel. Thus, the diffusion coefficient of P in DMT was much lower than that of water. In this research, we used the value of $5.8 * 10^{-6}$ $\mathrm{cm}^{2} \cdot \mathrm{s}^{-1}$ in calculating of $\mathrm{C}_{\mathrm{E}}$ for DGT and $5.54 * 10^{-8} \mathrm{~cm}^{2} \cdot \mathrm{s}^{-1}$ in calculating $\mathrm{C}_{\mathrm{DMT}-\mathrm{HFO}}$. 
TABLE 1

CHARACTERISTICS OF 10 CALCAREOUS SOILS USED IN THIS STUDY

\begin{tabular}{|c|c|c|c|c|c|c|c|c|}
\hline Soil & pH & $\begin{array}{l}\text { Olsen- P } \\
\text { mg kg }^{-1}\end{array}$ & CCE & $\begin{array}{c}\text { OC } \\
\mathrm{g} \mathrm{kg}^{-1}\end{array}$ & $\begin{array}{c}\text { Clay } \\
\mathrm{g} \mathrm{kg}^{-1}\end{array}$ & $\begin{array}{c}\text { Silt } \\
\mathrm{g} \mathrm{kg}^{-1}\end{array}$ & $\begin{array}{l}\text { Sand } \\
\mathrm{g} \mathrm{kg}^{-1}\end{array}$ & $\begin{array}{c}\text { Soil Textural } \\
\text { Class }\end{array}$ \\
\hline 1 & 8.2 & 16.6 & 4.8 & 8.1 & 70 & 150 & 780 & loamy sand \\
\hline 2 & 8.3 & 10.1 & 17.9 & 4.6 & 200 & 270 & 530 & sandy loam \\
\hline 3 & 8.3 & 5.2 & 13.5 & 8.5 & 540 & 300 & 160 & clay \\
\hline 4 & 8.3 & 11.1 & 9.7 & 20 & 220 & 340 & 440 & loam \\
\hline 5 & 8.4 & 21.8 & 6.7 & 8.3 & 320 & 360 & 320 & clay loam \\
\hline 6 & 8.2 & 9 & 6 & 12.7 & 490 & 360 & 150 & clay \\
\hline 7 & 7.8 & 12 & 5.7 & 9.5 & 180 & 310 & 510 & loam \\
\hline 8 & 8.2 & 17.3 & 23.8 & 15.6 & 340 & 500 & 160 & silty clay loam \\
\hline 9 & 8 & 3.1 & 24 & 8.1 & 280 & 380 & 340 & clay loam \\
\hline 10 & 8.1 & 24.6 & 22.1 & 9.5 & 180 & 510 & 310 & silt loam \\
\hline
\end{tabular}

pH of a 1:2 extract (soil: distilled water), Olsen-P, CCE, SP and OC are soil available P, calcium carbonate equivalent, saturation percentage and soil organic carbon, respectively.

\section{B. Field study}

By measuring and correlating of plant $\mathrm{P}$ content $(\mathrm{P}$ concentration in plant*plant dry matter), $\mathrm{C}_{\mathrm{DMT}-\mathrm{HFO}}, \mathrm{C}_{\mathrm{E}}$ and $\mathrm{P}$ extracted by Olsen method or test, we obtain a prediction of the potential $\mathrm{P}$ supply for plants by studied soils. We tested DMT-HFO and calculated $\mathrm{C}_{\text {DMT-HFO }}$ in times $24,72,240$ and 500 hours on studied soils to evaluate optimum deployment time of DMT-HFO (Fig. 6, 7). The results showed that based on $\mathrm{r}^{2}$ concept, the correlations between $\mathrm{C}_{\mathrm{DMT} \text {-HFO }}$ and plant $\mathrm{P}$ content on shoot increased with deployment time. According to the $r^{2}$ value, the lowest and highest correlation were related to 24 hours $\left(r^{2}=0.22\right)$ and 500 hours $\left(r^{2}=0.9\right)$, respectively (Fig. 6). Therefore, in 500 hours, we were able to explain $90 \%$ of the variation $\left(\mathrm{r}^{2}=0.90\right)$ in shoot $\mathrm{P}$ content. The $\mathrm{P}$ pool that is easily available to plants in a short time was referred to fast release kinetics and are comprised $\mathrm{P}$ bound to the reactive surfaces and are in direct contact with the aqueous phase [36]. Also, Koopmans et al. [37] have described that the $\mathrm{P}$ pool with slow release kinetics was related to sesquioxide aggregates and available only over a long period of time. The P extracted by DMT-HFO in short times was probably related to $\mathrm{P}$ pool with fast release kinetics and that is probably why the correlation was weaker but the P extracted by DMT-HFO in long period of time was probably related to the both of $\mathrm{P}$ pools and showed a strongly significant correlation with $\mathrm{P}$ content of shoots.
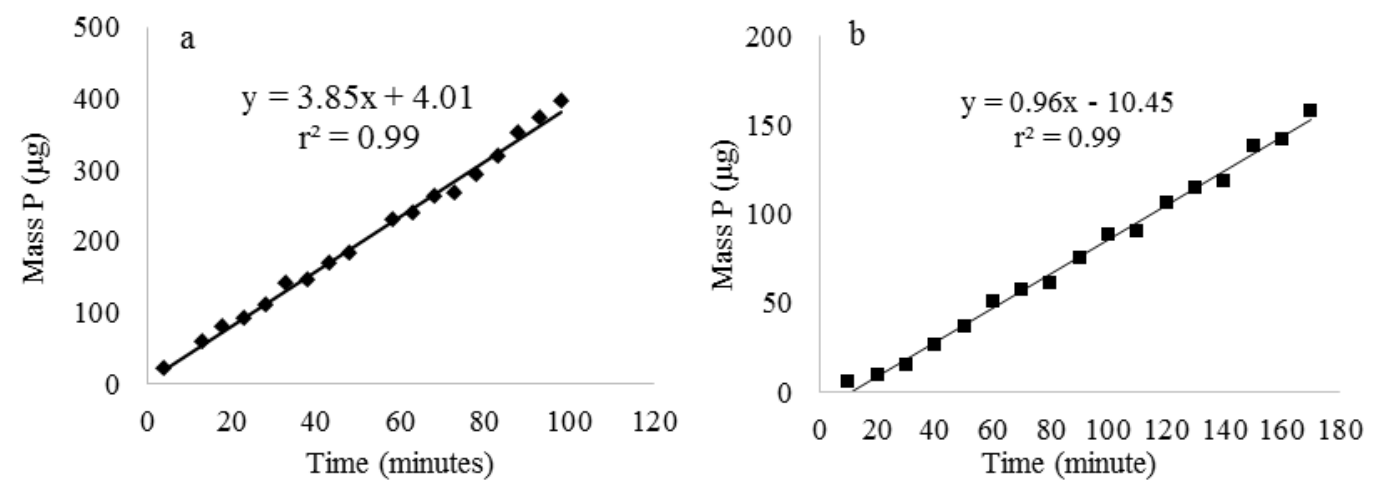

Fig. 5 Mass of phosphorus for different times during a diffusion experiment at $25{ }^{\circ} \mathrm{C}$. The fitted line corresponds diffusion coefficient for $\mathrm{KH}_{2} \mathrm{PO}$. $\mathrm{A}$ ) $6.9 * 10-6$ $\mathrm{cm}^{2} \cdot \mathrm{s}^{-1}$ in DGT B) $1.1 * 10^{-7} \mathrm{~cm}^{2} \cdot \mathrm{s}^{-1}$ in DMT 

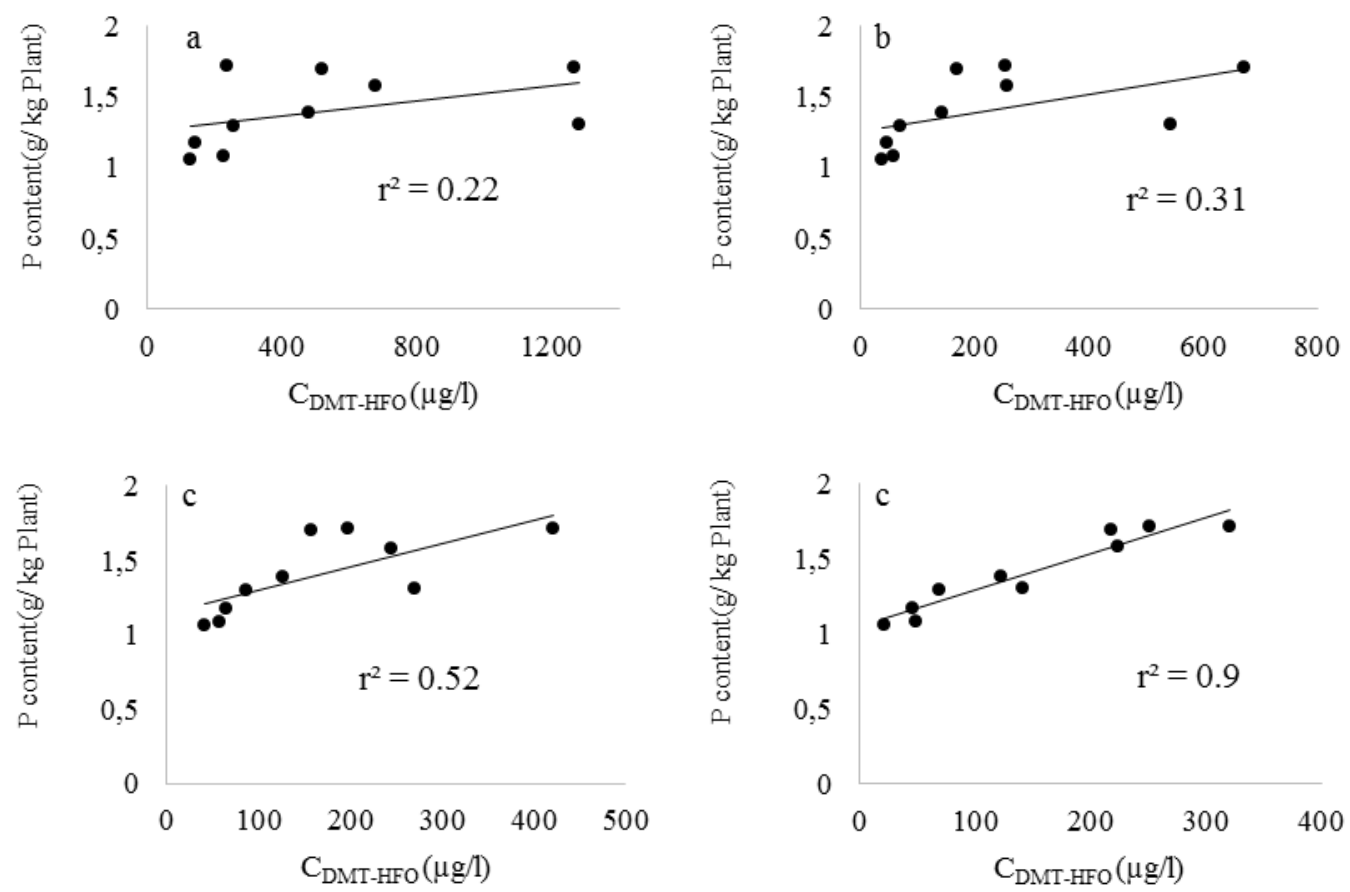

Fig. 6 The relationship of P content on corn shoots with P extracted by DMT-HFO) in a) 24 hours b) 72 hours c) 240 hours and d) 500 hours
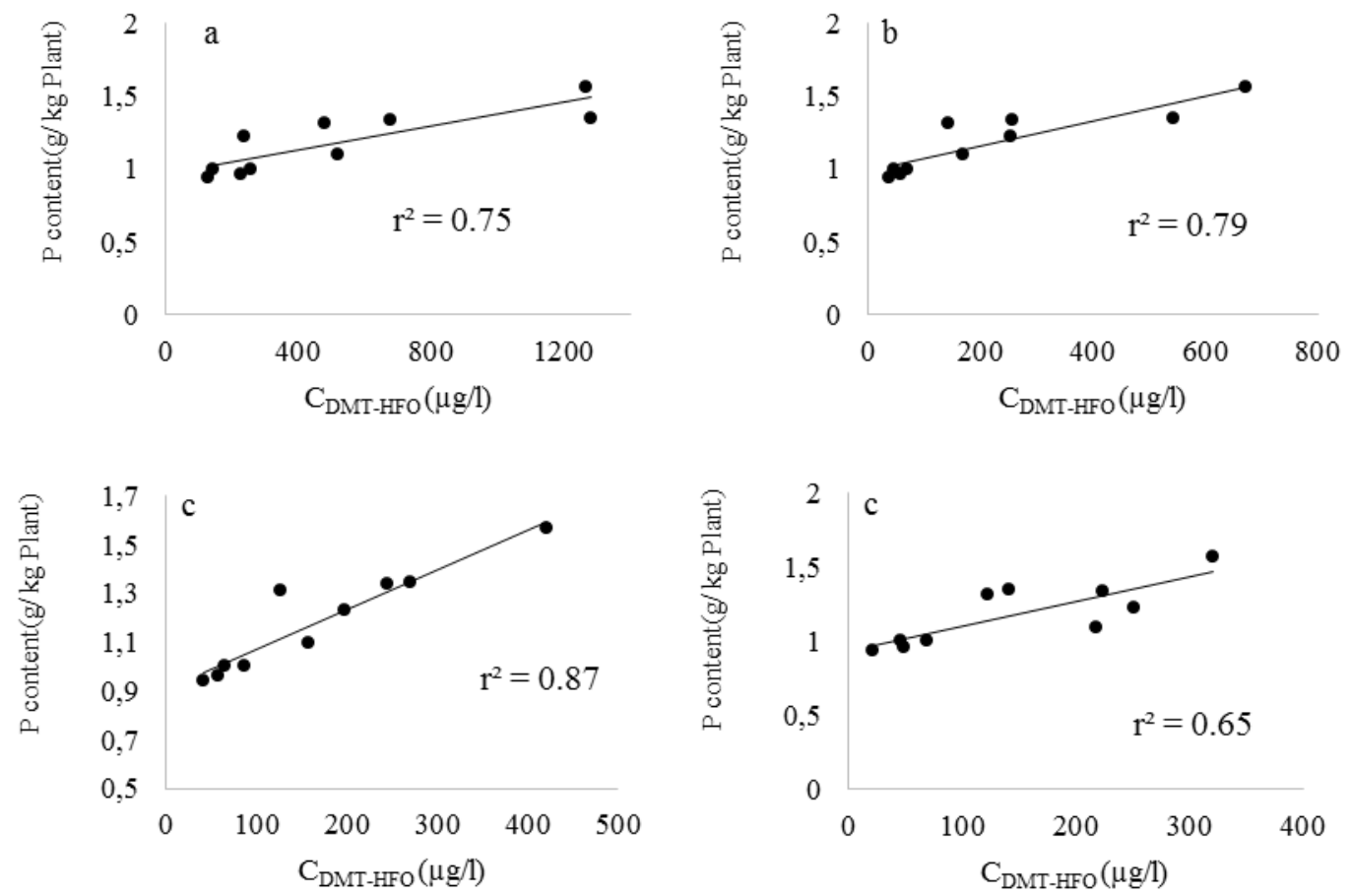

Fig. 7 The relationship between corn root P content with P extracted by DMT-HFO method) on times a) 24 hours b) 72 hours c) 240 hours d) 500 hours 

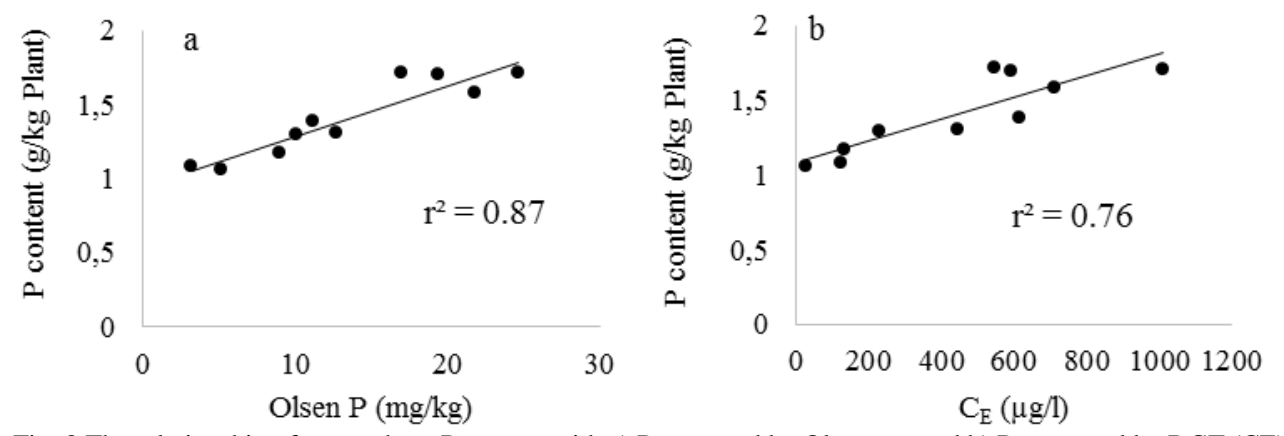

Fig. 8 The relationship of corn shoot P content with a) P extracted by Olsen test and b) P measured by DGT (CE)
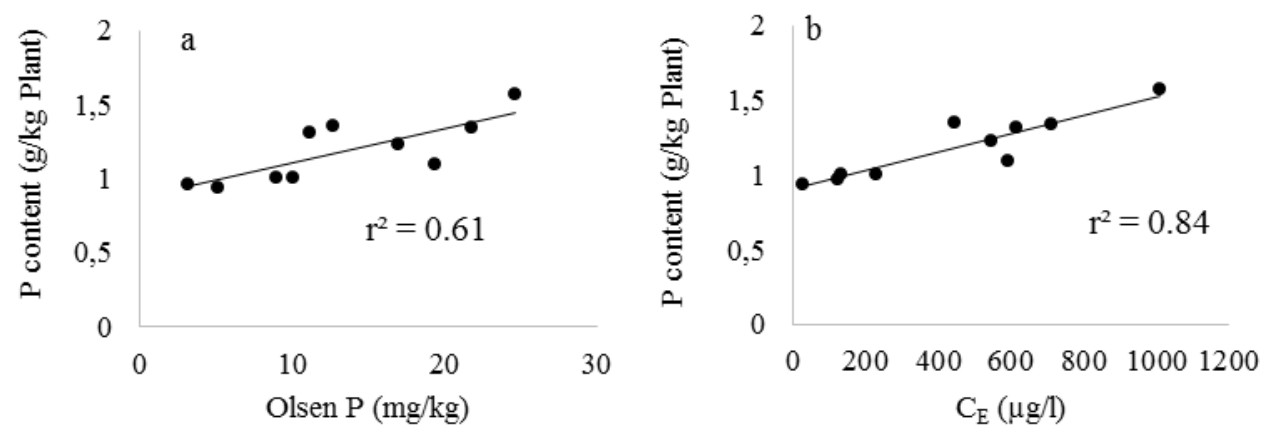

Fig. 9 The relationship of corn root $\mathrm{P}$ content with a) $\mathrm{P}$ extracted by Olsen test and b) $\mathrm{P}$ measured by DGT (CE)

The results showed that the relation between CDMT-HFO and plant $\mathrm{P}$ content of roots increased with deployment time to 250 hours and decreased to 500 hours based on $\mathrm{r}^{2}$ value (Fig. 7). The close correlation was in 250 hours. However, in 24 to 250 hours, the statistical correlations based on $\mathrm{r}^{2}$ concept were very similar. Taddesse et al. [38] was declared that fast release of $\mathrm{P}$, approximately within the first two weeks and after that a slower release were happened. The correlations between CDMT-HFO and plant roots $\mathrm{P}$ content based on $\mathrm{r}^{2}$ value were showed that probably the plant uptake on roots was related to fast release kinetics. By increasing the deployment time, the release of $\mathrm{P}$ was controlled by slow diffusion and the correlation was decreased.

The relationship between $\mathrm{C}_{\mathrm{E}}$ and Olsen-P with shoot $\mathrm{P}$ content is shown in Fig. 8. In this study, based on $\mathrm{r}^{2}$ concept, the parameters of $\mathrm{C}_{\mathrm{E}}$ and Olsen-P were able to explain $76 \%$ and $86 \%$ of the variation $\left(r^{2}=0.76\right.$ and $\left.r^{2}=0.86\right)$ in shoot $\mathrm{P}$ content, respectively. $\mathrm{C}_{\mathrm{E}}$ showed the close correlation with $\mathrm{P}$ content of roots $\left(\mathrm{r}^{2}=0.84\right)$ (Fig. 9). Also, the correlations between Olsen-P and concentrations in soil by the DGT $\left(\mathrm{C}_{\mathrm{E}}\right)$ were significant $\left(\mathrm{p}<0.05, \quad \mathrm{r}^{2}=0.84\right)$ (Fig. 10). Many researchers have found a good relationship between Olsen $\mathrm{P}$ and plant $\mathrm{P}$ content for individual soils, especially in calcareous soils [39-41]. Unlike our study, Tandy et al. [7] observed no relationship between Olsen $\mathrm{P}$ and $\mathrm{P}$ content of barley leaf but $\mathrm{C}_{\mathrm{E}}$ showed the best correlations $\left(\mathrm{r}^{2}=0.72\right)$ in their experiment. This may possibly related to soil $\mathrm{pH}$ value. They used soils with neutral or acidic $\mathrm{pH}$ (5-7). Menzies et al. [14] have described that the bicarbonate extraction including Olsen $\mathrm{P}$ and Colwell $\mathrm{P}$ advance for calcareous soils. P transports form soil particle to roots are controlled mainly by desorption kinetics. DGT like plant roots(regardless of biological reactions) act as a sink for $\mathrm{P}$ which causes lowering of $\mathrm{P}$ concentration in soil solution and re-supply from the solid phase [42]. In comparison to extraction methods, DGT uses soil moisture conditions close to reality. Therefore, it could better imitate the $\mathrm{P}$ diffusion restriction to plant roots [2].

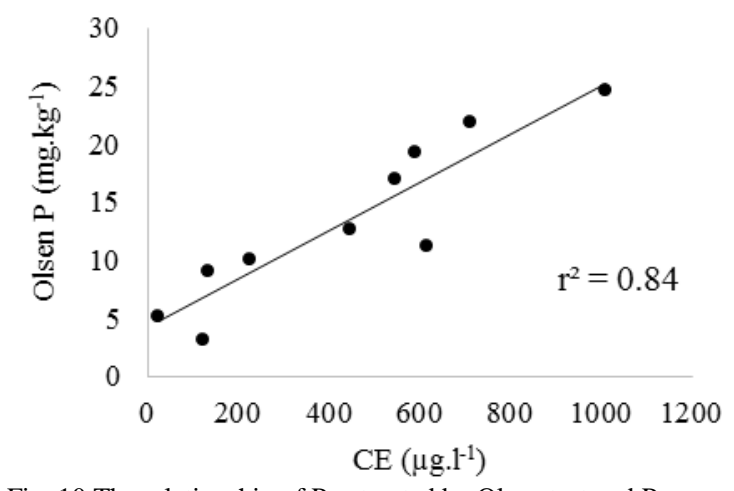

Fig. 10 The relationship of $\mathrm{P}$ extracted by Olsen test and $\mathrm{P}$ measured by DGT (CE)

\section{CONCLUSIONS}

This study was carried out to evaluate the performance of DGT and DMT-HFO devices (as new and relatively new techniques, respectively) as well as Olsen method (as a conventional method in calcareous soils) and comparing them to assess corn $\mathrm{P}$ content. This research showed that the diffusion through the DMT might be the rate-limiting step and this condition might simulate $\mathrm{P}$ release kinetics in soils with slow release kinetics. The amount of $\mathrm{P}$ extracted by DMT-HFO showed high correlations with corn P content. Although, soil test results in shorter times were more 
appropriate like extraction or DGT methods but the DMTHFO method can use to assess the availability of residual $\mathrm{P}$ in soils. This research would have benefitted by inclusion of more plant species and more soil types and could also be conducted in field scales which better simulates the conditions of plant $\mathrm{P}$ absorption in real situation.

\section{REFERENCES}

[1] Grant, C., et al., Soil and fertilizer phosphorus: Effects on plant P supply and mycorrhizal development. Canadian Journal of Plant Science, 2005. 85(1): p. 3-14.

[2] Mason, S., et al., Prediction of wheat response to an application of phosphorus under field conditions using diffusive gradients in thinfilms (DGT) and extraction methods. Plant and soil, 2010. 337(1-2): p. 243-258.

[3] Reuter, D., Plant analysis: an interpretation manual. 1997: CSIRO publishing.

[4] Olsen, S.R., et al., Estimation of available phosphorus in soils by extraction with sodium bicarbonate. U.S. Dep. of Agric. Circ., 1954. 939.

[5] Nelson, W., A. Mehlich, and E. Winters, The development, evaluation, and use of soil tests for phosphorus availability. Agronomy, 1953. 4(2): p. 153-188.

[6] Bray, R.H. and L. Kurtz, Determination of total, organic, and available forms of phosphorus in soils. Soil science, 1945. 59(1): p. $39-46$.

[7] Tandy, S., et al., The use of DGT for prediction of plant available copper, zinc and phosphorus in agricultural soils. Plant and soil, 2011. 346(1-2): p. 167-180.

[8] Menon, R.G., S.H. Chien, and L.L. Hammond, Development and evaluation of the $\mathrm{Pi}$ soil test for plant - available phosphorus. Communications in Soil Science and Plant Analysis, 1990. 21(13-16): p. $1131-1150$.

[9] Zheng, Z. and T. Zhang, Soil phosphorus tests and transformation analysis to quantify plant availability: A review. 2012: INTECH Open Access Publisher.

[10] De Jager, P. and A. Claassens, Long - Term Phosphate Desorption Kinetics of an Acid Sandy Clay Soil from Mpumalanga, South Africa. Communications in soil science and plant analysis, 2005. 36(1-3): p. 309-319.

[11] Koopmans, G., et al., Selective extraction of labile phosphorus using dialysis membrane tubes filled with hydrous iron hydroxide. Soil science, 2001. 166(7): p. 475-483.

[12] Zhang, H. and W. Davison, Performance characteristics of diffusion gradients in thin films for the in situ measurement of trace metals in aqueous solution. Analytical Chemistry, 1995. 67(19): p. 3391-3400.

[13] Zhang, H., et al., A new method to measure effective soil solution concentration predicts copper availability to plants. Environmental science \& technology, 2001. 35(12): p. 2602-2607.

[14] Menzies, N.W., B. Kusumo, and P.W. Moody, Assessment of P availability in heavily fertilized soils using the diffusive gradient in thin films (DGT) technique. Plant and soil, 2005. 269(1-2): p. 1-9.

[15] Nolan, A.L., H. Zhang, and M.J. McLaughlin, Prediction of zinc, cadmium, lead, and copper availability to wheat in contaminated soils using chemical speciation, diffusive gradients in thin films, extraction, and isotopic dilution techniques. Journal of Environmental Quality, 2005. 34(2): p. 496-507.

[16] Six, L., E. Smolders, and R. Merckx, The performance of DGT versus conventional soil phosphorus tests in tropical soils-maize and rice responses to P application. Plant and Soil, 2012: p. 1-18.

[17] Barrow, N.J. and T.C. Shaw, Sodium bicarbonate as an extractant for soil phosphate, I. Separation of the factors affecting the amount of phosphate displaced from soil from those affecting secondary adsorption. Geoderma, 1976. 16(2): p. 91-107.

[18] Demetz, M. and H. Insam, Phosphorus availability in a forest soil determined with a respiratory assay compared to chemical methods. Geoderma, 1999. 89(3-4): p. 259-271.

[19] Dahlqvist, R., et al., Performance of the diffusive gradients in thin films technique for measuring $\mathrm{Ca}$ and $\mathrm{Mg}$ in freshwater. Analytica Chimica Acta, 2002. 460(2): p. 247-256.
[20] Zhang, H. and S. Young, Characterizing the availability of metals in contaminated soils. II. The soil solution. Soil Use and Management, 2005. 21(s2): p. 459-467.

[21] Sochaczewski, Ł., et al., 2D DGT induced fluxes in sediments and soils (2D DIFS). Environmental Modelling \& Software, 2007. 22(1): p. 14-23.

[22] Thomas, G., Soil pH and Soil Acidity. In 'Methods of soil analysis. Chemical methods'.(Ed. DL Sparks) Soil Science Society of America: Madison, WI, 1996: p. 475-490.

[23] Gee, G.W., J.W. Bauder, and A. Klute, Particle-size analysis. Methods of soil analysis. Part 1. Physical and mineralogical methods, 1986: p. 383-411.

[24] Allison, L. and C. Moodie, Carbonate. Methods of Soil Analysis. Part 2. Chemical and Microbiological Properties, 1965(methodsofsoilanb): p. 1379-1396.

[25] Nelson, D. and L. Sommers, Total carbon, organic carbon and organic matter. In 'Methods of soil analysis. Part 3. Chemical methods'.(Ed. DL Sparks) pp. 961-1010. Soil Science Society of America: Madison, WI, 1996.

[26] Freese, D., et al., New method for assessment of long-term phosphate desorption from soils. Soil Science Society of America Journal, 1995. 59(5): p. 1295-1300.

[27] Zhang, H. and W. Davison, Diffusional characteristics of hydrogels used in DGT and DET techniques. Analytica Chimica Acta, 1999. 398(2-3): p. 329-340.

[28] Zhang, H., et al., In situ measurement of dissolved phosphorus in natural waters using DGT. Analytica Chimica Acta, 1998. 370(1): p. 29-38.

[29] Hooda, P., et al., Measuring bioavailable trace metals by diffusive gradients in thin films (DGT): soil moisture effects on its performance in soils. European Journal of Soil Science, 1999. 50(2): p. 285-294.

[30] Chiari, M., et al., Electrophoretic separation of biopolymers in a matrix of polyacrylamide covalently linked to agarose. Electrophoresis, 1996. 17(3): p. 473-478.

[31] Santner, J., et al., Ferrihydrite containing gel for chemical imaging of labile phosphate species in sediments and soils using diffusive gradients in thin films. Analytical chemistry, 2010. 82(18): p. 76687674.

[32] Van Veldhoven, P.P. and G.P. Mannaerts, Inorganic and organic phosphate measurements in the nanomolar range. Analytical biochemistry, 1987. 161(1): p. 45-48.

[33] Waling, I., et al., Soil and plant analysis, a series of syllabi: Part 7 Plant Analysis ProceduresWageningen Agriculture University, 1989.

[34] Olsen, S.R. and L.E. Sommers, in Methods of soil analysis. Part 2. Chemical and microbiological properties, Phosphorus,. American Society of Agronomy, Madison, WI, 1982: p. 403-430.

[35] Davison, W., H. Zhang, and G.W. Grime, Performance characteristics of gel probes used for measuring the chemistry of pore waters. Environmental science \& technology, 1994. 28(9): p. 1623 1632.

[36] Lookman, R., et al., Long-Term Kinetics of Phosphate Release from Soil. Environmental Science \& Technology, 1995. 29(6): p. 15691575 .

[37] Koopmans, G., et al., Phosphorus availability for plant uptake in a phosphorus-enriched noncalcareous sandy soil. Journal of environmental quality, 2004. 33(3): p. 965-975.

[38] Taddesse, A., A.S. Claassens, and P. De Jager, Long-term kinetics of phosphate desorption from soil and its relationship with plant growth. South African Journal of Plant and Soil, 2008. 25(3): p. 131-134.

[39] Ahmad, W., et al., Bioavailability of Inorganic Phosphorus Fractions in Calcareous Soils Estimated by Neubauer Technique, Iron Impregnated Filter Paper, and Chemical Tests. Communications in soil science and plant analysis, 2006. 37(9-10): p. 1185-1193.

[40] Mostashari, M., et al., Phosphorus fractions of selected calcareous soils of Qazvin province and their relationships with soil characteristics. Am Eurasian J Agric Environ Sci, 2008. 3(4): p. 547553.

[41] Delgado, A., M.d.C. Del Campillo, and J. Torrent, Limitations of the Olsen method to assess plant - available phosphorus in reclaimed marsh soils. Soil use and management, 2010. 26(2): p. 133-140.

[42] Mason, S., et al., Investigating chemical constraints to the measurement of phosphorus in soils using diffusive gradients in thin films (DGT) and resin methods. Talanta, 2008. 74(4): p. 779-787. 